This article is available open access under a CC BY-NC-ND 4.0 license as part of Berghahn Open Anthro, a subscribe-to-open model for APC-free open access made possible by the journal's subscribers.

\title{
Contesting the Social Contract
}

Tax Reform and Economic Governance in Istria, Croatia

Robin Smith

\begin{abstract}
This article investigates how Istrian business owners challenged the Croatian government's motivation for and enforcement of fiskalizacija, an automated VAT reform adopted in 2013 as Croatia prepared for EU membership. Fiskalizacija threatened local economic agency and sowed distrust in government. The analysis of this tax reform demonstrates how Istrians envisage their economic agency, rights, and responsibilities. I argue that it is not just the construction of fiscal systems, but how such a system is projected onto society that is fundamental to the development of state-society relations. The way in which a tax reform is put into effect, including the enforcement practices of state agents, shapes how citizens perceive the social contract to be constituted by fiscal regimes.
\end{abstract}

Keywords: Croatia, economic agency, economic governance, family business, fiskalizacija, state-society relations, tax reform

Visiting Gino's northwestern Istrian winery, I found his sister Elena at their computer. ${ }^{1}$ She was troubleshooting a new value-added tax (VAT) payment program, phoning an IT office as tourists impatiently waited for their receipts in the wine tasting room. Elena had wrongly input the charge for their wine and was frantically trying to resolve it. She explained that the system debited VAT from their account immediately and paid it to Carina, the Croatian national tax office. This was problematic if the sale had been input incorrectly, which happened regularly due to the program's idiosyncrasies. This program is colloquially known as fiskalizacija, which approximately translates as 'fiscalizing' and refers simultaneously to the computer program and the VAT legislation around 
it. Although Gino's winery was one of the most professionalized locally, Elena was struggling to use the program correctly.

The government adopted fiskalizacija in 2013 before Croatia joined the EU. Its purported objectives were to decrease informal business practices, streamline business administration, and instill an ethos of tax compliance that the state surmised was lacking due to the pervasiveness of unregistered businesses working in the gray market. Istrian business owners, however, disagreed, arguing that fiskalizacija built on Western stereotypes of Eastern Europeans as tax evaders who prefer working in the informal economy. Such stereotypes were embedded in early reforms advanced by international organizations and have lingered as countries join the EU. "The government doesn't trust us!” Gino exclaimed, upset that fiskalizacija applied only to registered businesses like his own trying to abide by the state's ever-changing legislation and paying other taxes as well. Unregistered ones, he grumbled, would continue operating as before. This threatens registered business owners selling in the same market with higher costs than their neighbors who are evading regulations and taxation. As Bejaković (2009: 791, 797) notes, many Croatians distrust government, regard the tax administration as inefficient and corrupt, and view state employees as fairly incompetent. This set the tone for the policy rollout. Fiskalizacija's intensified government scrutiny on already tax-paying companies created a feeling that business owners were a target for generating government revenue. People were angry, and the myriad issues with implementing the policy amplified this. The final straw was that fiskalizacija failed to address a basic issue of high priority to all business owners during the economic crisis then ravaging Europe: clients were failing to pay their bills for months-sometimes yearswithout penalty.

To families like Elena's, fiskalizacija felt threatening in important ways. Getting things right in the bureaucracy of everyday commerce is the priority of family business owners who cannot afford to risk high fines or other penalties that would immediately impinge on their livelihoods. Additionally, being a successful entrepreneurial family defines one's economic agency and confers an important social status. The mode of fiskalizacija enforcement seemed to threaten both values. Ultimately, fiskalizacija highlighted a mutual distrust: the state suspected that citizens are aspirant tax evaders, and citizens suspected that the state does not want them to unseat the economic elite. By juxtaposing contract enforcement to tax inspections, Istrians argued that fiskalizacija reflected the government's disciplinary bent rather than adherence to a particular fiscal philosophy.

Thus, we must go beyond considering whether a particular tax is just or how to interpret the motivations of tax compliance, which have been the focus of much research (Braithwaite 2003; Kirchler 2007). Although it is important to investigate local modes of resistance to bring insights into how state-citizen relationships are defined by fiscal reforms (Abelin 2012; Guano 2010), it is 
apparent that we should also think about how tax reforms are implemented and how tax practices influence the way people perceive the social contract. This is particularly salient in states like Croatia, where national values, norms, and beliefs may still need to find voice in legislation adopted with the consultation of foreign institutions after the end of socialism and the break-up of Yugoslavia. I believe that understanding tax practices must go beyond compliance to include how people perceive their relationship with the state through fiscal relations. Fiskalizacija exemplifies how aggressive tax enforcement may constitute a coercive state tactic (Bourdieu 1994)—one that fundamentally challenges state-society relations. It shows that the way state agents engage with citizens shapes the latter's perceptions of their relationship with the state and informs their understanding of its economic governance values. On this basis, people evaluate their economic values against the governance authority shaping their economic lives to determine the justness of the economic governance system to which they are subjected. My argument is that how a tax regime is implemented influences citizens' perceptions of the social contract. In other words, understanding tax reforms necessitates that we understand how people perceive their relationship with the state via fiscal relations. As such, tax collection is a practice that constitutes the social contract.

Based on 28 months of fieldwork among small business owners in the northwestern Istrian locality of Bujština, I argue that fiskalizacija reframed the social contract. In the following sections I show how Istrians demanded a fiscal contract that reflected local economic values in terms of their own economic agency in and over the region's economy, as well as their economic governance expectations of the state. First, to understand such demands, one must appreciate Bujština's unique and historical syncretic market characteristics as a border territory separating then socialist Yugoslavia and Italy, and the particular economic values stemming from this. Today, Istria's location on Croatia's border with Slovenia-barely 20 kilometers from Italy and remote from the national capital Zagreb-locates Istrians' demands for an economic governance that encapsulates the value of economic self-determination for both the region and individual citizens. Following from this, discussions about fiskalizacija extended beyond a taxes-for-services paradigm. Rather, residents addressed larger issues: Istria's place in Croatia, participation in European integration, the development of governance institutions, and local economic values. Business owners framed their rejection of fiskalizacija in terms of economic rights and governance obligations, pointing to the behavior of fiscal inspectors and legal lapses by government to enforce contracts to bolster their claims. Thus, I show how fiskalizacija's implementation worked to reveal Istrians' perceptions of their role in economic governance processes and their relationship to government, and the expectations they had of a social contract. 


\section{The Roots of Istrian Economic Values}

When talking about local government, people in Bujština frequently compared the current situation with the past. When it was part of Yugoslavia, prior to the federation's collapse in the 1990s, " 80 percent of Istria's revenues were used for local development. Today only 8 percent stays, the rest goes to Zagreb," one friend explained. The numbers, of unknown provenance, changed depending on the narrator, but the sentiment was the same: in Yugoslavia, Istrians knew how their taxes were being used and had a say in it, but today they feel that the taxes they pay evaporate into Croatia's national budget for reallocation somewhere unknown. The Yugoslav organization of the economy, which was called 'self-management', encouraged participation in structures like workers' councils and trade unions in then state-owned firms. The economic future of local firms was the community's responsibility, and the health of the local economy was inextricably linked to decisions in these structures. Within them, workers voted to tax their income for community projects. People cited kindergartens, bus stops, and the hundreds of kilometers of paved roads as results of such voluntary, self-imposed taxation-personal contributions that remain visually apparent today. Self-management was about local problem solving instead of having outsiders intervene to fix local economic problems (Duda 2019). Those who had participated in self-management structures emphasized that voting on company expenditures meant people knew where their money had gone and that this was evidence of voluntary taxation. Over time, making decisions about what was being taxed shaped communities and engrained the value of participatory economic governance. Self-management continues to be an important facet of personal narratives for former management and employees who became private entrepreneurs in the 1990s. There was no conceptual separation between their responsibility for their economy and that for their community. Self-management cultivated a sense that economic governance over Istria was both a right and a responsibility.

That Bujština was part of the Free Territory of Trieste (hereafter, Free Territory), which granted Yugoslav Istrians the right to do business in Italy within that zone, also contributed to the feeling of regional economic autonomy. There existed not only wide latitude for commerce, but also a clear division between the Yugoslav state's role in the economy and that of the Istrian regional government. Economic interests were considered a social right (Woodward 1995: 166-167), whereby the state's legitimacy rested on economic health and growth (ibid.: 16). Economic performance was the focus for "generating popular acquiescence to state socialist rule" (Irvine 1997: 7) and legitimating government more broadly. With regard to Istrian market activities, this translated to a hands-off approach by Tito, the then president, as a thriving border region served his interests. Functionally, this meant that neither production controls 
on families nor cross-border trade within the Free Territory was enforced. Indeed, former state-owned firm administrators recall that, in order to engage in Western European commerce and circumvent export controls, it was common for private companies throughout Yugoslavia to have offices in Bujština.

Thus, I would characterize Bujština and the Free Territory as having been a particular syncretic market, as it and its market actors embodied aspects of two economies with fundamentally different ideological tenets. This market syncretism, along with Istria's broad mandate to economically self-govern, generated a vibrant small family business sector, one where self-actualization was achieved through market activities. Although there were regulations preventing direct competition with state firms, such as not allowing families to bottle and label their wines to compete with state wineries, Istrians could sell almost unrestricted volumes of agri-food produce in Italy within the Free Territory.

Perhaps because of this experience, today a fully realized Istrian is someone with a successful family business. Surnames are often used in business names, especially among winemakers but also other artisanal food producers prevalent in the region. Community recognition of one's economic agency occurs through participation in village fairs that showcase artisanal agri-food products with friendly competitions, whose winners are subsequently publicized in the region's newspaper Glas Istre. Family businesses are valued for making the community resilient through their market success, which allows them to fund charity events and pool resources for local projects. The family business is thus seen as a status symbol, but it is also bound up with the identity of Istria more broadly.

In sum, it was apparent that self-management and doing business in the Free Territory were central to local narratives about Istria's fiscal relationship to Zagreb. This shaped notions of economic self-governance and the vibrant family business sector's cultivation of a family-centric economic agency. However, there is a concomitant history that undergirds relations with the state in which Istrians have been accused of being irredentist because of their pre-World War II Italian heritage. In these accounts, assertions of being 'not real Croatians' and 'dangerous' have often been levied against Istrians by Croatians from other parts of the country. In the context of the wars of the 1990s, when borders were being redrawn, Istria's Italian heritage was considered threatening to Croatian nationalists, who feared an underlying irredentist movement would reincorporate Istria into Italy (Ballinger 2003: 251), despite the fact that there never had been an independence movement in the region (Ashbrook 2006: 625; Baskar 1999). Not only were Italian cultural institutions especially active in Istrian community life, but they were (and still are) financially supportive, aiding schools, community centers, theatres, and even rural development projects such as planting Italian olive tree varietals. In the 1990s, such activities were viewed with suspicion. National leaders like President Tuđman's then nationalist Croatian Democratic Union (HDZ) party characterized Istrians as politically 
untrustworthy due to Istria's historical economic, political, and cultural connections to Italy (Cocco 2010: 14). When the Istrian Democratic Party (IDS) was established in 1994, this confirmed to many the region's irredentist tendencies, particularly because the IDS promoted regional issues that were viewed as too protectionist and showed an interest in participating in European institutions (Ashbrook 2006: 639; Lindstrom 2008: 195).

The region's economic self-governance intensified after the 1990s wars from which Istria was largely spared. Whereas other regions had to focus financially on recovery and reconstruction, Istria could concentrate elsewhere, and over subsequent decades increasingly invested in its own development. The IDS supported the establishment of institutions that helped finance rural development, like the Istrian Development Agency (IDA). The IDA negotiated with banks to offer low-interest and delayed-payment loans to modernize family farms and cooperated with the national Tourist Board to promote rural tourism. These efforts led to the proliferation of wineries, olive mills, dairies, honey producers, handicraft makers, and agro-tourisms (farmstead restaurants with B\&B lodgings). The IDS coordinated with European institutions that made available additional financing for such activities. VinIstra, Istria's wine association, began an annual trade fair oriented toward public wine education. It hosted international wine figures, established production and taste guidelines for the indigenous white wine varietal Malvasia, promoted Istria as 'the new Tuscany', and showcased technological winemaking advancements. Istria's rapid development as the leading Croatian wine region and a European culinary tourism hotspot followed. Such efforts facilitated rural residents making a living from small-scale farming and raised recognition of Istria's contribution to the national budget. They also reinforced the notion that the region's business sector had a broad mandate to actively intervene in shaping the local economy. However, such economic values were challenged by the new national taxation regime emanating from Zagreb. This led to both great resentment toward state actors and increased distrust of the state more broadly.

\section{Resentment, Compliance, and the Social Contract}

The basic tenet of the social contract in modern times is thought of as ceding some level of personal autonomy by voluntarily submitting to a fiscal relationship in return for protections and benefits that only state-like institutions can deliver. Bourdieu (1994: 7) has framed taxation as the basis of unifying a territory of people who, via tax, are submitting to the same obligations. That said, a tax perceived to be unjust may be met with resistance in an attempt to 'adjust' the terms of the relationship in order to rectify the injustice (Fjeldstad and Semboja 2000: 21). Insights about how taxation emerges in contested ways 
to redefine state-citizen relations have led to theorizations of fiscal relationships as constituting a kind of economic or fiscal citizenship. Roitman's (2007) 'economic citizenship' demonstrates how citizens may demand rights to economic security vis-à-vis their state's fiscal actions. In contrast, Guano’s (2010) 'fiscal citizenship' unravels how questions of taxation equity and the allocation of state benefits define a relational category between state and society. Such works help us understand the deeper value of tax to individuals and how citizens interpret the social contract.

Meanwhile, resistance to taxation has been demonstrated as being centered on the feeling that citizens are not receiving sufficient social services in return. For example, ethnographic accounts of resistance unpack how taxpayers may claim that government bureaucracy is inefficient (Abelin 2012) or nepotistic (Guano 2010), or that the government is incapable of managing specific programs like pension funds (Begim 2018) to ground their claims. Forms of what Roitman (2005) aptly calls 'fiscal disobedience' may result, ranging from street protests (Abelin 2012) to individual tax evasion (Sedlenieks 2003). These anthropologists demonstrate how individuals weigh the justness of the benefits and protections they receive against the tax burden (Björklund Larsen 2018: 49). Such research thus focuses on a specific tax owed to the state and whether it is legitimate in the eyes of those paying it, interrogating how citizens interpret what they get out of adhering to the social contract.

Other tax scholars have primarily analyzed resistance in terms of compliance with specific fiscal regimes. They often take a policy angle to problematize how states may encourage compliance. Thus, they may focus on citizens' responses to sales, income, or inheritance taxes to understand how to increase revenues (Boll 2014a; Braithwaite 2003; Gracia and Oats 2012). They find that compliance is influenced by the way in which reforms are implemented (Wynter and Oats 2019). Some focus on strategies created to build trust or "ethical values" (Alasfour 2019: 243) within society to increase compliance, while others analyze how trust in authorities and their relative power may bring about compliance (Kirchler 2007). Some scholars investigate how auditors make those working in the informal economy visible to the state in order to widen the tax base (Boll 2014b). Others consider how a state may have to 'earn' tax revenue by cultivating its relationship with citizens to increase their willingness to pay (Gatt and Owen 2018: 1196).

Similarly, Croatian academics have reflected that compliance might increase were the state "more responsible towards citizens" (Bađun 2007: 213). They have newly focused on the professional behavior, tax knowledge, and education of inspectors and how these factors influence citizens' trust in and compliance with tax regimes (Cipek 2018: 251, 262). Recently, the Croatian government even adopted reforms based on the Dutch system, chosen because of the nation's high compliance rate, which the government considered a 
"novelty" because it is focused "more on cooperation than repression" (ČičinŠain 2016: 847, 849). However, such research and policy initiatives build on literature that details how to increase compliance, feeding into a narrative that citizens are inherently tax evaders, and that the state's goal should be to decrease this evasion via stricter measures.

Taking such research as a point of departure, I suggest that it is not just the construction of fiscal systems that is fundamental to the development of state-society relations; it is also how such a system is projected onto society. The literature fails to consider that the way a tax reform is implemented, and the associated enforcement practices of state agents, may have fundamental implications for how citizens perceive the social contract to be constituted by fiscal regimes. While taxation may be read as a state's project of social transformation, disciplinary technique, and even 'social engineering' (Bush and Maltby 2004), Bourdieu (1994: 6) argues that coercive tactics by state agents give impetus to questioning the legitimacy of the fiscal regime itself.

Thus, certain ways of implementing a taxation regime, and indeed some specific types of taxation, may be more deleterious to than constructive of a stronger state-society relationship. The mode by which a state implements a reform has consequences for society in practical terms and in terms of society's perceptions of government, from its intent to its underlying values. The tactics of state agents to recuperate taxes, and the precedent it sets for future state-society relations, is an example of how taxation is part of the state's social engineering. Fiskalizacija is illustrative of such a case.

While scholars like those above have paid attention to how people resist taxation reforms in terms of the social contract, less attention has been paid to how a tax's implementation works to constitute the social contract. Istrians did not contest the legitimacy of VAT, despite it being the highest in Europe at 25 percent, but rather the way that the state enforced it. Inspectors' aggressive enforcement led to a groundswell of distrust. Fiskalizacija made apparent to business owners that the state only cared to enforce one side of the social contract. Inspectors' punitive tactics threatened livelihoods. This is important because economic interventions that increase economic precarity are particularly problematic in post-socialist Yugoslav states, where access to a 'normal' standard of economic livelihood is considered a social right (Radošević and Cvijanović 2015; Woodward 1995: 166). The right to earn a normal livelihood from family-based businesses is the basis of local self-understanding. The right to the market is therefore regarded as an inalienable one, rather than a right that can be accessed only by paying taxes (see Roitman 2007: 195).

Istrians thus reject state efforts to distill the relationship to a basic taxesfor-services paradigm that reduces them to fiscal citizens, insisting instead that the method of taxation and how it is implemented work to constitute the social contract. Although taxation creates a fiscal relationship, its method of 
implementation affects how people perceive the social contract, particularly in a newly constituted post-socialist state. Fiskalizacija's implementation showed how a fiscal regime may even reveal new economic cleavages.

\section{Local Discontent with Zagreb’s Economic Governance}

That afternoon in the wine tasting room, when Elena was struggling with the software program, she pointed out that fiskalizacija was a burden to families because of the program's high cost, which required many business owners to buy new computers and upgrade their Internet access. It was also stressful because one could not cancel a sale once it has been sent to Carina, making a mistake risky. She explained that Carina had no technical support office, having outsourced installation to IT companies. Thus, when business owners called with problems, Carina officials referred them back to local IT technicians. However, the technicians would correctly explain they could not reverse an incorrectly submitted sale or tax payment as they were not a government institution. Elena worried out loud about the implications for her mistakes: incorrectly inputting sales would mean that taxes would be repeatedly over- or underpaid, and that inventory would be wrong at a surprise inspection. Her family discussed how it would be worse if they paid less than required because this would look like tax evasion. Either way, they risked penalties that could include fines, temporary closure, or blocked accounts.

Situations like these heightened tensions between business owners and government, as the complexity and costs of business ownership rose, and highlighted how business owners were now the target of state fiscal disciplinary techniques. Elena lamented that the VAT from such small transactions hardly benefited the national budget, being of much less value than the taxed transactions of large conglomerates, known to be evading myriad taxes. But the winery's daily struggle with fiskalizacija made the state increasingly felt in family life.

Elena's problems were made worse by the fact that at the time of fiskalizacija's adoption, long-term non-payment between businesses was pervasive, with arrears of 6 to 12 months being common. Poorly functioning courts made recuperating debts especially burdensome. For business owners, this was a crisis of economic governance that threatened their livelihoods. Protection from non-payment would safeguard their economic agency, but fiskalizacija failed to address this. Many rural business owners rely on wholesale transactions to hotel restaurants, supermarkets, or food-processing factories. Legislation allows businesses 90 days to pay such bills. However, fiskalizacija's automated system disaggregates VAT from the price of the good: it debits the seller's account 25 percent VAT immediately, before a bill has necessarily been paid. In the interim-which could legally be up to 90 days, but in practice is much 
longer-the seller is out of pocket due to both the VAT and the price of the good. This compounds liquidity and debt problems. Since business-to-business transactions are often for large volumes of goods, such as 30,000 euros of wine sold to a supermarket, fiskalizacija quickly threatened businesses with insolvency, leading to protests. Istrians pointed out this inequity in their resentment toward the reform: fiskalizacija guarantees that the seller immediately pays VAT on the product sold, ensuring that the state is paid, but it does not guarantee that the buyer actually pays for the product any time soon. Fiskalizacija failed to address the issue of recovering arrears and introduced a new way to add to business owners' liquidity problems, thus sowing deep discontent and compounding financial burdens.

Highlighting this dichotomy became the primary way Istrians expressed their frustration with Zagreb's economic governance. The payment of taxes was the state's priority, whereas receiving payment for goods was citizens' priority. Simply put, Istrians juxtaposed fiskalizacija to a different but central payment issue important to every business person in the economy: contract enforcement. Contract enforcement is central to market functioning and a basic state responsibility. In this sense it is a core benefit of being a citizen. However, as one businessman said in reference to his clients: "There is no shame in not paying. It has become 'in style' to see if you can get away with it." He explained that the mark of a 'good' businessman has become showing that he can get away with not following the rules and avoid paying his debts. Stories circulated about the convoluted legal process surrounding recuperating debts, judges who colluded with defendants, and unsatisfactory settlements, all of which dissuaded business owners from initiating legal action against debtors. As a result, so-called buyers knew that their clients would not go to court.

One restaurateur, Marino, lamented: "Contracts do not help because nothing can save you from non-payment." He recounted his own experience chasing 100,000 kuna $(13,500$ euros) from one debtor to illustrate how the paltry contract enforcement was viewed as a blight on the economy. The judge recommended that Marino enter mediation with the debtor, warning him that otherwise the debtor could "just close his company and open another one the next day, and I would get no money at all," Marino related. Ultimately, after years of waiting, paying for paperwork, and meeting with lawyers, Marino received less than one-third of the debt. Other business owners told of instances in which the court ruled that the debtor must pay in full, but they never received payment because the debtor repeatedly appealed. So even winning in court is no guarantee of payment. Such stories reveal that high legal costs, trial waiting times of three or more years, and other factors make it impractical to chase smaller debts.

Italo, a winemaker, drew on a similar story while filling bottles. In explaining that a majority of local wines are sold to restaurants and wine bars, he added that "the buyer has no legal reason to pay for the good" after Italo pays 
the VAT through fiskalizacija because there is no practical way to enforce payment. From his perspective, he loses both the cash on his account necessary to pay fixed costs, like utilities, salaries, ${ }^{2}$ and inputs, and the goods he hypothetically could have sold to tourists instead. His largest buyer, a seaside hotel, may buy 250,000 kuna (33,800 euros) of wine in one day, for which Italo immediately pays 62,500 kuna in VAT. One can see it is problematic that fiskalizacija guarantees only that the seller pays VAT on the product sold, not that the buyer actually pays for the product any time soon, as a business may quickly become illiquid. This is an important distinction for business owners like Italo who primarily depend on business-to-business transactions. This characterizes most Istrians in agri-food production, but anyone in an intermediary business may find themselves in a similar plight. He continued: "It's not a problem to sell my wine-my product moves. The problem is to get paid for it! This is Croatia!" As in Elena's situation, Italo was expressing frustration that fiskalizacija ultimately raised costs by debiting his account for VAT without securing payment for the goods on which this tax was paid.

This was a sentiment repeated by every business owner I spoke with about fiskalizacija. Highlighting evident distrust in the state, another businessman, Alessio, explained the underlying logic:

It is not in the state's interest [to enforce payment] because VAT has already been paid ... The state is only interested in ensuring it is paid, not that we are ... It is not honorable that the buyer does not pay. The seller is anxious because he must pay utilities, salaries of workers, and other costs. To me, it is the buyer who should be paying the state its VAT, not the seller. VAT is the major problem. This raises our costs and makes us less competitive in Europe, because we are waiting for payment and have to take out loans to cover costs.

This reflects business owners' belief that what fiskalizacija should do is to create a working market economy. Resistance was rooted in the observation that government was upholding only half of the social contract: the half making sure that it was paid. Business owners contended that by not focusing on the issue of arrears, the state was tacitly condoning the practice. Fiskalizacija laid bare beliefs around how an economy should be governed-by whom, through what processes, and with what effects. As such, fiskalizacija illuminated the problematic of how the social contract is locally constituted and whether it is being honored. Here, the local narrative pitted fiskalizacija against the social contract. People like Elena juxtaposed the state's failure to resolve arrears to its aggressive enforcement of fiskalizacija. This one-sidedness underpinned their claims of disenfranchisement and the unjustness of fiskalizacija. Notions of a social contract around taxation-for-rights centered on the difficulty of realizing their individuated economic agency as family 
businesses if they had to pay VAT before they were paid for their goods, or were constantly threatened with fines or closure. It made the traditional social contract of taxes-for-services seem inequitable, a feeling only reinforced by the behavior of tax inspectors.

\section{Tax Inspectors: A Threat to Economic Agency}

In the hillside town of Buje in the summer of 2013, four shops-a seamstress, hair salon, photography studio, and mini-market-were shuttered in one week by undercover fiskalizacija inspectors posing as customers. Walking through town, it was eerie to see the darkened windows of shops with tax bureau tape across the doors and official notices with state seals at eye level explaining the reasons for the closures. Marina, a Buiese café owner, told me the seamstress's story as she made coffee. The seamstress was approached at the close of business by a woman wanting a skirt hemmed. She stayed late, but as her working hours were until 6:00 PM and the receipt was time-stamped at 6:15 PM, the undercover inspector fined her for issuing a receipt after closing. Marina continued, saying that a similar situation befell the hair salon owner, who was fined by an inspector posing as a customer near closing time asking for a trim. The photography studio and mini-market were behind in tax payments, a waiter at another café related. After these conversations, I took a walk and read the notices taped on the shops' façades. The way that these stories had been recounted was far from neutral. In the first two instances, the inspectors were cast as immoral tricksters preying on small business persons who were simply being flexible to customers coming with late requests. In the latter two instances, the waiter's explanation for their tax delinquency was that virtually everyone is behind on bills to state agencies, and since this is inevitable for small businesses, they were unjustly singled out. In all four cases, the immorality of the state actors was the focal point, and the overarching narrative was one of critiquing Zagreb's competence at economic governance, especially because shuttering businesses was perceived as diminishing one's economic position in society.

Shops whose registers had mistakes of 50 kuna (6.70 euros) were fined 10,000 kuna and shuttered for anywhere between 5 and 30 days during the peak of tourist season (Ivanović 2013; Pavić 2013). Fiskalizacija required electronically generated receipts with every transaction and mandated that registers balance during open hours. This made things complicated for service-oriented businesses where it is common practice for patrons to simply leave cash on the bar. Marko, another Buiese café owner, expressed his frustration by citing a local incident where a popular seaside restaurant was closed because its register was off by 150 kuna. Instead of paying the fine, the owner shuttered 
permanently, moved to Austria, and reopened an old business there. Marko was angry that local businesses were closing for good due to such infractions.

Another business owner animatedly recounted how an inspector instigated non-compliance by deliberately avoiding a receipt. He allegedly ran from the bar, only to return to fine the owner for failing to hand him the receipt. Indeed, this came on the heels of a nationally publicized episode where a waiter-also a former footballer-ran to hand a receipt to an undercover inspector fleeing his establishment (Lucić 2013). Other cafés were temporarily closed for putting tips in the register. Such inspector behavior was the primary topic of conversation among small business owners.

Marcello, a winemaker, described how a man visiting his cellar asked to buy 50 liters of wine in compressed-air steel canisters, preferred by restaurants serving wine by the glass. The man aggressively negotiated for 20 minutes, offering to buy the wine for a discount but without a receipt to help Marcello avoid VAT. Marcello threw him out, saying he refused to sell to such a rude person. The man soon returned, revealed that he was an inspector, and tried to shake Marcello's hand. Marcello recounted that he challenged the inspector: "Why did you push me so hard? That is unfair." The inspector replied that he was just doing his job. Marcello lamented: "They are trying to trick and then catch us." The inspector acted like it was a game, but it was one that threatened Marcello's livelihood. He followed this with his family's story: a man who posed as a distributor took 100,000 kuna worth of their wine and disappeared without paying, leaving Marcello answerable for 25,000 kuna in VAT. They have since been waiting over three years for the state to investigate. He juxtaposed the visiting inspector's behavior in attempting to trick him into breaking the law to the state's failure to enforce the rule of law and find the wine thief. To Marcello, this was sufficient evidence to justify his claim that the state has failed as a steward of the economy and does not care about small businesses, but rather regards them as potential sources of income. The state cannot be trusted to protect his family from economic theft, but it has the authority to trick him into breaking the law. Seen from this vantage point, it becomes clear how fiskalizacija fomented distrust in the state.

Inspectors' behavior was also analyzed in the wider context of poor economic governance through the enforcement of fiscal regulations. This offered an even starker contrast to the coordination and focus of inspectors on fiskalizacija. At his winery, Franco told about a recent encounter with an inspector. He had sold 300 bottles of wine at 40 kuna (5.40 euros) per bottle to a nearby police station. The police served it at a charity event, but never paid or issued Franco with a receipt. Subsequently, inspectors visited Franco's winery, found an inventory discrepancy of 300 bottles, and issued a fine. After confronting the police, Franco received a receipt and sent it to the inspectors, who rescinded the fine. They then demanded that Franco pay 3,000 kuna VAT on 
the wine's value on this new receipt. He was exasperated at the hypocrisy of one state institution (financial inspectors) punishing him while another (police force) was allowed to ignore the law and not pay its debt. When confronted, the inspectors explained that they have no enforcement power over the buyer because they are financial inspectors of businesses. In closing his story, Franco commented: "People here study how to steal."

Finally, Istrians focused their grievances on the issue of shaming debtors. The public debt notices were embarrassing in a community defined by family businesses. Successful families, like Elena and Gino's and others whose stories were told above, are often also representatives of Istrian culture. Inspections immediately translate into threats to a business's reputation. A public announcement of Elena's 'tax evasion', even if unintentional from her poor understanding of fiskalizacija's computer interface, could become gossip, and could even turn into a story that the family is successful because of their 'tax evasion'. Adding insult to injury, the state, ostensibly in the name of transparency, launched a website that lists tax debtors and the amount they owe and is popularly cited in newspaper articles about business closures. A Buiese shopkeeper retorted that the state should not put businesses like the neighboring photography studio on the same website as national conglomerates in debt to the state for millions of kuna. He laboriously searched the website to show the range of debts. The rationale for focusing on small businesses, he and others surmised, was that it is easier to spot-check them than to undertake a financial audit of a large corporation. He gave the example of Agrokor, a corporation known to owe millions. He noted that Agrokor's 60,000 employees would be displeased with the government were they to temporarily or permanently lose their jobs from the company's closure in a market already suffering high unemployment. He explained: "It is unfair ... If I pay and he does not, and he drives a nice new car and I cannot, who is stupid and who is smart? We are the stupid ones, working hard and gifting our products to people who have no intention to pay us and no shame in not paying us." Such lamentations and lay theorizations about state behavior-whether it was the behavior of inspectors or the types of businesses (small family or large conglomerates) targeted for inspection-demonstrate how fiskalizacija tapped into pre-existing statesociety fissures.

Thus, Istrians did not resist VAT as unjust, but rather contested the inequity of fiskalizacija's enforcement, which targeted the economic agency of family businesses, and its non-comprehensive scope. That the state seemingly lacked the economic governance proficiency to resolve pervasive, long-term arrears that were straining businesses, but had the capacity to send multitudes of undercover inspectors across the country to undercut the economic agency of business owners and penalize tiny infractions, undergirded Istrians' feeling of disenfranchisement. People believed that the state was simply unwilling, rather than unable, 
to address the arrears issue. The intense enforcement of only half of a business transaction - the one guaranteeing the state its revenue-felt at odds with what should have been the greater economic governance goal of creating a well-functioning market. Business owners contended that inroads to achieving this could be made by protecting their contracts, and that this would improve revenues better than chasing small discrepancies. Fiskalizacija reached beyond a discussion of tax policy to encompass state behavior writ large. The gaps clearly apparent in the government's fiscal agenda seemed so basic that a profound lack of trust emerged; the assumption prevailed that this error was strategic rather than accidental. Istrians expected to maintain their economic agency as family businesses engaging in the economy and contributing to the development of Istria's image as an entrepreneurial farming region characterized by artisanal food products, as a culinary tourism destination, and as one of Europe's niche wine regions. Enforcement seemed to unduly target Istrian family businesses, and a narrative emerged that inspectors were more aggressive here than elsewhere in Croatia.

\section{Becoming a 'Normal' European Economy}

"We Istrians are too honest!" Marcello exclaimed as he worked in his cellar. He leapt into an anecdote then circulating about how inspectors visiting Dalmatian seaside restaurants were wooed with tables of food into not issuing fines for fiskalizacija infractions. By suggesting that Istrians pay taxes more willingly than business owners in other Croatian regions, he was tapping into the narrative of Istria's financial centrality to claim economic recognition. It echoed an older local narrative about how important Istria's tax revenue was to Yugoslavia's budget, often alluded to in various ways to emphasize Istria's important position in Yugoslav history and defend against the insidious trope of Istrians as irredentist. Efforts of small business owners to comply reflected their desire to be regarded as good Croatians. Although fiskalizacija was a nationwide program, however, some spoke as if it had been adopted solely to punish Istria's economy. Some like Marcello felt Istria was a target of enforcement because of its private sector strength.

To counter negative perceptions, Istrians look for ways to mention their valuable contribution to national wealth. For example, Glas Istre publishes the tourism tax revenue totals on a sometimes weekly basis as front page news during summer tourist season. Fiskalizacija joined the headlines that summer, periodically publishing the increase in revenue resulting from its adoption and concomitant inspections. ${ }^{3}$ This opened an opportunity for Istrians to claim that although it is geographically peripheral, Istria is financially central to Croatia because its high number of registered small businesses and its robust tourism sector contribute tax revenue. 
Nevertheless, there was a widespread belief that fiskalizacija was not normal-not just in its implementation in Istria, but as a fiscal policy in general. This was in large part due to cross-border relationships. Istrian families have been doing business in Italy since the socialist era due to their inclusion in the Free Territory. Since Croatia's independence, their commerce with nearby Italy, Austria, Germany, and Slovenia has intensified. Winemakers, for example, regularly deliver minivans of wine to these countries, returning home with anecdotes from clients' conversations about how 'normal' economies work.

In discussions about fiskalizacija, such anecdotes provided a stark contrast to the Croatian state's economic governance failure to create a healthy market economy. Some business owners (including Italo and Alessio mentioned above) made oblique references comparing Croatia and nearby EU countries to ground their claims that Croatia's fiskalizacija is abnormal. Indeed, in a normal transaction in a normal economy, it is the buyers who pay VAT at the point of sale when they purchase a product, as the tax is embedded in the total price. In adopting fiskalizacija, the Croatian government decoupled purchases into two separate transactions-enforcing the payment of the tax but not the payment for the goods being sold.

However, the dichotomy Istrians articulated between these economies went much deeper. For example, in speaking about his financial situation and fiskalizacija, a farmer named Giuseppe told me:

This is our [version of] liberal capitalism, and either you accept it or you will be punished. It is worse than a dictatorship. During socialism, sure, I could not speak against Tito, but why would I? Life was good then. I could live. Now, I vote and my representatives work against my interests, and if I complain I am punished ... Our European democracy is not your American democracy. It is not Lincoln and the Constitution. Here, the law changes five times per year, you don't know what it is and whether you are breaking it, but you will definitely pay for it eventually, that is for sure!

Echoing this sentiment, a Bujština politician stated: “The government is behaving like its citizens are its enemies. They don't help us, even though helping the people is the state's purpose. Instead, we citizens are serving the government as they steal our wealth. People can't make it in life. We have a political crisis." It was clear from such conversations that fiskalizacija was symbolic of a greater struggle in society. Viewed as emblematic of the inequity of many other economic reforms, the tax reform adopted in 2013 was considered symptomatic of a divergence from what Istrians thought were Western norms to a predatory capitalism run amok.

Such reactions revealed a belief that the social contract should be composed of more than taxes for services. Instead, Istrians hold an expansive view of their economic prerogatives, envisage a trenchant distribution of rights and 
responsibilities between state and society, and have a clear expectation of how economic governance should be legitimately executed. Fiskalizacija and its mode of implementation in their community became a way to express their discontent with how this social contract was constituted in comparison to nearby countries and their recent economic history. There was a feeling of loss in economic self-determination, beyond nostalgia for socialism's quality of life guarantees as narrated in ethnographic accounts about 'normal lives' (Jansen 2014). The myriad 'normal life' narratives found in post-socialist spaces are bound together with the common thread of economic disenfranchisement and disenchantment with reforms meant to align the region with the EU's West (see Fehérváry 2002; Greenberg 2011). Istrians felt that they had experienced market capitalism in the socialist era due to Bujština's market syncretism and considerable economic self-governance, which included decision making in self-management institutions and keeping some revenues from family businesses and socialist industry. By contrast, this new taxation regime made it apparent to them that the social contract is only partially constituted by the state's creation of a market that allows private businesses to maintain their economic agency in exchange for contributing to the state's revenue.

Business owners insisted that the buyer should be liable for the VAT, which highlights how Istrians pinpointed fiskalizacija's inherent illogical foundation around which to voice their opposition. However, the narratives of disappointment with the government in the context of fiskalizacija's implementation also highlight how citizens may frame such narratives to question the government's underlying intent. The combination of aggressive inspectors and paucity of state interventions to enforce contracts contributed to the feeling that the state regards the private sector primarily as a revenue source. That large conglomer-

ates were known to be evading taxes further fed such impressions. Fiskalizacija not only galvanized Istrians to voice both disenchantment with reforms and a desire for a normal economy, but also led them to formulate a targeted policy critique of government that questioned the underlying logic and intent of the reform. Fiskalizacija, they challenged, made it impossible for people to do business normally-which is all the more ironic when one remembers that it was adopted in the midst of Croatia joining the EU.

\section{Concluding Remarks: The Social Contract and Economic Values}

Fiskalizacija revealed that for Istrians the ability to collectively contribute to regional economic governance, through local decision making and individual economic activity, was an integral aspect of their self-definition. Their vision of the social contract as something enacted through individual behavior reflecting particular economic governance values was at odds with Zagreb's. Historical 
personal market experiences, knowledge about how economies work elsewhere, and fundamental local economic values surrounding agency and self-determination together informed Istrian conceptualizations of the social contract.

This article has argued that the way a tax regime is implemented, and the associated enforcement practices of state agents, has fundamental implications for how citizens perceive the social contract to be constituted by fiscal regimes. Local framing of disenfranchisement focused on underlying intent, juxtaposing the predatory behavior of inspectors against the issue of poor contract enforcement. From this, a narrative emerged of fiskalizacija as anti-Istrian, anti-small business, and predatory. Articulations of the social contract were infused with expectations grounded in local understandings of good economic governance, rooted in Istrians' past personal experiences of living in a border zone and engaging in trade with Italy during the socialist era. Participating in Bujština's syncretic market cultivated their particular understanding of how markets function and their economic governance values. The implementation of fiskalizacija demonstrated how long-standing geopolitical fractures may find new salience, creating unanticipated fissures between state and society that become new grounds for distrust. It revealed the economic governance shortcomings and contradictions of Zagreb, which failed to protect against arrears while managing to use fiskalizacija to increase its revenues, not so much by increasing general tax compliance in the informal or formal economies, but by increasing punitive measures for small episodes of non-compliance by otherwise tax-compliant businesses.

The fiscal exchange relationship apparent in Yugoslavia seemed to evaporate in post-socialism as Istria's economic self-governance grew. If the question framing post-socialist Europe's future in the 1990s was, 'what was socialism, and what comes next?' (Verdery 1996), the answer increasingly seems to be that rather than free market capitalism, Croatia is transforming into a managed market reminiscent of a kind of 'managerial capitalism' (Eyal et al. 1998) governed more opaquely than Yugoslavia's self-management. To Istrian business owners, the state was now seeking to restrict their economic agency in ways not done during the socialist era. They read fiskalizacija as an attempt to reduce their relationship with the government to transactional terms, or, worse, as a sign that the government did not care about small businesses.

Fiskalizacija became a centerpiece around which to hang their governance expectation of the protection of contracts, and ultimately their governance discontent when the state failed to do so. The decoupling of VAT from payment for products compounded this cleavage in economic governance values. The immediate debiting of VAT constricted business owners' economic agency by pushing them into or near insolvency as they waited for buyers to pay. Unable in the meantime to make investments, pay bills, or otherwise continue everyday business, they instead spent their time chasing debts. Fiskalizacija thus 
created an opportunity to highlight the state's failure to fulfill expectations of facilitating a healthy economic environment-one where contracts were honored and debts paid-and a robust, functioning market that favored the small business sector.

Rather than turning to informal business practices, Istrian business owners revealed their willingness to embrace modern business norms. However, the complications met in adopting these norms on a practical level gave energy to narratives of a self-interested, predatory state. The shuttering of businesses for minor infractions was starkly contrasted to the large debts of major corporations. Thus, fiskalizacija, achieved most thoroughly by aggressive, undercover inspections, contributed to breaking the public's trust. Its unintended consequences were that core economic governance values were challenged, business owners' sense of their economic role in their communities was diminished, and the individuated economic agency of family businesses felt threatened. Narratives underpinning Istrians' resistance to fiskalizacija revealed their particular understanding of the social contract, and fiskalizacija's perceived shortcomings provided a framework around which Istrians could articulate their vision of economic agency and good economic governance.

\section{Acknowledgments}

This article was written while conducting postdoctoral research on the project "Food Citizens? Collective Food Procurement in European Cities: Solidarity and Diversity, Skills and Scale" funded by the European Research Council under the European Union Horizon 2020 research and innovation program (Grant No. 724151) at Leiden University, the Netherlands. Research for this article was undertaken in Istria, Croatia (2012-2014), and I am greatly indebted to the families who opened their lives to me. I wish to thank Nicolette Makovicky, Cressida Jervis Read, our anthropology of tax network, and Robert Parkin for their transformative feedback. I would also like to thank the two anonymous reviewers.

Robin Smith is a Political Economy Fellow of the Independent Social Research Foundation at the Oxford School of Global and Area Studies, and a Fellow of St Antony's College, University of Oxford. She is an anthropologist most interested in agricultural, food, finance, and environmental issues. Her research has benefited from the financial support of the Clarendon Fund, New College Oxford Graduate Scholarship, and American Council of Learned Societies. E-mail: robin.smith@area.ox.ac.uk 


\section{Notes}

1. Interlocutors' names have been changed, and translations are my own, unless otherwise indicated.

2. The average salary of a cellar worker is 800 euros per month.

3. These data support Istrians' feeling of significantly contributing to the national revenue. Bronić and Franić (2014: 342) found that between 2002 and 2010, "the region with [the] highest fiscal capacity [GDP per capita], Istria, collected approximately three times as much revenue from regional taxes ... as the region with the lowest." Older data also show that Istria's high tax revenues were redistributed to other regions (Bajo and Bronić 2004).

\section{References}

Abelin, Mireille. 2012. “'Entrenched in the BMW': Argentine Elites and the Terror of Fiscal Obligation.” Public Culture 24 (2): 329-356.

Alasfour, Fadi. 2019. "Costs of Distrust: The Virtuous Cycle of Tax Compliance in Jordan.” Journal of Business Ethics 155 (1): 243-258.

Ashbrook, John. 2006. "Locking Horns in the Istrian Political Arena: Politicized Identity, the Istrian Democratic Assembly, and the Croatian Democratic Alliance.” East European Politics and Societies 20 (4): 622-658.

Bađun, Marijana. 2007. "Book Review: N. Hayoz and Simon Hug. 2007. Tax Evasion, Trust, and State Capacities. Bern: Peter Lang." Financijska Teorija i Praksa 31 (2): 211-213. https://hrcak.srce.hr/16166.

Bajo, Anto, and Mihaela Bronić. 2004. "Fiskalna Decentralizacija u Hrvatskoj:

Problemi Fiskalnog Izravnanja” [Fiscal decentralization in Croatia: Problems of fiscal equalization]. Financijska Teorija i Praksa 28 (4): 445-467.

Ballinger, Pamela. 2003. History in Exile: Memory and Identity at the Borders of the Balkans. Princeton, NJ: Princeton University Press.

Baskar, Bojan. 1999. "Made in Trieste: Geopolitical Fears of an Istrianist Discourse on the Mediterranean." Narodna Umjetnost 36 (1): 121-134.

Begim, Ainur. 2018. "How to Retire Like a Soviet Person: Informality, Household Finances, and Kinship in Financialized Kazakhstan.” Journal of the Royal Anthropological Institute 24 (4): 767-785.

Bejaković, Predrag. 2009. "Tax Evasion, State Capacity, and Trust in Transitional Countries: The Case of Croatia.” Društvena Istraživanja 18 (4-5): 787-805.

Björklund Larsen, Lotta. 2018. A Fair Share of Tax: A Fiscal Anthropology of Contemporary Sweden. Basingstoke: Palgrave Macmillan.

Boll, Karen. 2014a. "Mapping Tax Compliance: Assemblages, Distributed Action and Practices: A New Way of Doing Tax Research." Critical Perspectives on Accounting 25 (4-5): 293-303.

Boll, Karen. 2014b. "Shady Car Dealings and Taxing Work Practices: An Ethnography of a Tax Audit Process.” Accounting, Organizations and Society 39 (1): 1-19. 
Bourdieu, Pierre. 1994. "Rethinking the State: Genesis and Structure of the Bureaucratic Field.” Trans. Löic J. D. Wacquant and Samar Farage. Sociological Theory 12 (1): 1-18.

Braithwaite, Valerie A., ed. 2003. Taxing Democracy: Understanding Tax Avoidance and Evasion. London: Routledge.

Bronić, Mihaela, and Josip Franić. 2014. "Level and Determinants of Regional Taxes in Croatia." Lex Localis: Journal of Local Self-Government 12 (3): 329-348.

Bush, Barbara, and Josephine Maltby. 2004. "Taxation in West Africa: Transforming the Colonial Subject into the 'Governable Person.” Critical Perspectives on Accounting 15 (1): 5-34.

Čičin-Šain, Nevia. 2016. "A New Approach of the Croatian Tax Administration towards Taxpayers Based on Cooperation Instead of Repression: A True Change in Attitude." Croatian and Comparative Public Administration 16 (4): 847-866.

Cipek, Ksenija. 2018. "Efikasnija Naplata Poreza i Sprečavanje Poreznih Utaja/ Evazija: Prevencija Protiv Represije” [More effective tax collection and the prevention of tax fraud/evasion: Prevention versus repression]. Zbornik Radova Pravnog Fakulteta u Splitu 55 (1): 251-263.

Cocco, Emilio. 2010. "Borderland Mimicry: Imperial Legacies, National Stands and Regional Identity in Croatian Istria after the Nineties.” Narodna Umjetnost 47 (1): $7-28$.

Duda, Igor. 2019. "Local Communities and Yugoslav Self-Management: Everyday Practices in Croatia in the 1980s." Paper presented at the Association for Slavic, East European, and Eurasian Studies 2019 conference panel "Yugoslav Self-Management in a Municipality," San Francisco, CA.

Eyal, Gil, Iván Szelényi, and Eleanor Townsley. 1998. Making Capitalism without Capitalists: Class Formation and Elite Struggles in Post-Communist Central Europe. London: Verso.

Fehérváry, Krisztina. 2002. "American Kitchens, Luxury Bathrooms, and the Search for a 'Normal' Life in Postsocialist Hungary.” Ethnos 67 (3): 369-400.

Fjeldstad, Odd-Helge, and Joseph Semboja. 2000. "Dilemmas of Fiscal Decentralisation: A Study of Local Government Taxation in Tanzania.” Forum for Development Studies 27 (1): 7-41.

Gatt, Leah, and Oliver Owen. 2018. "Direct Taxation and State-Society Relations in Lagos, Nigeria.” Development and Change 49 (5): 1195-1222.

Gracia, Louise, and Lynne Oats. 2012. "Boundary Work and Tax Regulation: A Bourdieusian View.” Accounting, Organizations and Society 37 (5): 304-321.

Greenberg, Jessica. 2011. "On the Road to Normal: Negotiating Agency and State Sovereignty in Postsocialist Serbia.” American Anthropologist 113 (1): 88-100.

Guano, Emanuela. 2010. "Taxpayers, Thieves, and the State: Fiscal Citizenship in Contemporary Italy.” Ethnos 75 (4): 471-495.

Irvine, Jill A. 1997. "Introduction: State-Society Relations in Yugoslavia, 19451992.” In State-Society Relations in Yugoslavia, 1945-1992, ed. Melissa K. Bokovoy, Jill A. Irvine, and Carol S. Lilly, 1-24. New York: St. Martin’s Press. Ivanović, M. Vermezović. 2013. "U Istri ovog Ljeta Zatvoreno Više od Stotinu Objekata” [More than a hundred businesses closed in Istria this summer]. Glas 
Istre, 4 September. https://glasistrenovine.hr/arhiva-portala/pregled-vijesti/ u-istri-ovog-ljeta-zatvoreno-vise-od-stotinu-objekata-422036.

Jansen, Stef. 2014. “On Not Moving Well Enough: Temporal Reasoning in Sarajevo Yearnings for 'Normal Lives.” Current Anthropology 55 (S9): S74-S84.

Kirchler, Erich. 2007. The Economic Psychology of Tax Behaviour. Cambridge: Cambridge University Press.

Lindstrom, Nicole. 2008. "Boundary-Making in Europe's Southeastern Margin: Balkan/Europe Discourse in Croatia and Slovenia." In The Geopolitics of Europe's Identity: Centers, Boundaries, and Margins, ed. Noel Parker, 195-206. New York: Palgrave Macmillan.

Lucić, Vlado. 2013. “Fiskalni Inspektor Slomio Nogu Bježeći od Konobara Koji Mu Je Nosio Račun” [Fiscal inspector broke his leg running away from the waiter delivering his receipt]. News Bar, 24 July. http://www.portaloko.hr/ clanak/fiskalni-inspektor-slomio-nogu-bjezeci-od-konobara-koji-mu-je-nosioracun-/0/48552/.

Pavić, Bojana Mrvoš. 2013. "I Zbog Napojnica u Kasi Inspektori Pečate Kafiće” [Inspectors close café due to tips in the register]. Glas Istre, 4 March. https:// glasistrenovine.hr/arhiva-portala/pregled-vijesti/i-zbog-mance-u-kasi-inspektori -pecate-kafice-388461.

Radošević, Dubravko, and Vladimir Cvijanović, eds. 2015. Financialisation and Financial Crisis in South-Eastern European Countries. Frankfurt: Peter Lang.

Roitman, Janet. 2005. Fiscal Disobedience: An Anthropology of Economic Regulation in Central Africa. Princeton, NJ: Princeton University Press.

Roitman, Janet. 2007. "The Right to Tax: Economic Citizenship in the Chad Basin.” Citizenship Studies 11 (2): 187-209.

Sedlenieks, Klavs. 2003. "Cash in an Envelope: Corruption and Tax Avoidance as an Economic Strategy in Contemporary Riga." In Everyday Economy in Russia, Poland, and Latvia, ed. Karl-Olov Arnstberg and Thomas Borén, 37-52. Stockholm: Södertörns Högskola.

Verdery, Katherine. 1996. What Was Socialism, and What Comes Next? Princeton, NJ: Princeton University Press.

Woodward, Susan L. 1995. Socialist Unemployment: The Political Economy of Yugoslavia, 1945-1990. Princeton, NJ: Princeton University Press.

Wynter, Carlene B., and Lynne Oats. 2019. “Knock, Knock: The Taxman's at Your Door! Practice Sense, Empathy Games, and Dilemmas in Tax Enforcement." Journal of Business Ethics. https://doi.org/10.1007/s10551-019-04300-x. 